\title{
A model for continued professional development with focus on inquiry-based learning in science education
}

\author{
Berit Kurtén ${ }^{1}$ and Ann-Catherine Henriksson ${ }^{2}$ \\ ${ }^{1}$ Åbo Akademi University, Vasa, Finland \\ ${ }^{2}$ Åbo Akademi University, Åbo, Finland
}

This is a qualitative study with a twofold aim. The first aim is to describe and analyse teachers' perceptions of advantages and challenges with a model for continued professional development (CPD) for primary school teachers. The CPD course was about inquiry-based learning (IBL) in science education. The second aim of the study is to analyse the teachers' thoughts after implementing inquiry-based methods in their own science teaching. The empirical data, in the form of video transcriptions, notes, interviews and results from electronic forms, were collected during and after four separate in-service courses for teachers $(\mathrm{N}=26)$. The analysis of the data is done through thematic analysis. As positive results, the teachers emphasised the implementation of IBL with their students and the individual mentoring, which were parts of the CPD model. Teachers highlighted the importance of students' possibilities to make investigations based on their own questions, which proved to have a positive impact on students' interest and motivation. Teachers also saw the importance of their own planning and goal setting. The results indicate that the teachers perceived a tension between having control and relinquishing control, which can become a challenge. Two other challenges were teachers' perceived lack of time for planning and implementing but also teachers' deficient subject knowledge.

\author{
ARTICLE DETAILS \\ LUMAT General Issue \\ Vol 9 No 1 (2021), 208-234 \\ Received 30 October 2020 \\ Accepted 8 April 2021 \\ Published 18 April 2021 \\ Pages: 27 \\ References: 67 \\ Correspondence: ann- \\ catherine.henriksson@abo.fi \\ https://doi.org/10.31129/ \\ LUMAT.9.1.1448
}

Keywords: primary teachers, inquiry-based learning in science, professional development model, teachers' perceptions, thematic analysis

\section{Introduction}

This study focuses on a continued professional development (CPD) course for primary science teachers in first through sixth grades in Finland. The CPD course was completed with four different groups of teachers. The theme of the CPD course, which lasted one year for each group, was inquiry-based learning in science, with focus on open inquiry. The challenge today for teachers is to educate their students for future challenges, described in the $21^{\text {st }}$ century skills (European Union, 2006). Lonka (2018, p. 68) describes this in the following way; "citizens need to understand the nature of scientific investigation and be able to interpret scientific evidence and conclusions". Inquiry-based teaching is a pedagogical approach where students can develop these skills. In the Finnish core curriculum (Finnish National Board of Education [FNBE], 2016), the objectives of research and working skills state that students should be able to formulate their own research questions and plan for small-scale research projects. 
These objectives compel teachers to develop their own competences for guiding the students in the process of learning the above-mentioned skills. The teachers participating in this study took an active part in their own learning, e.g., by planning for their students to carry out inquiry-based projects in science. The teachers created their own learning path by trying out inquiry-based thinking in their teaching, with individual mentoring from teacher trainers. The two teacher trainers responsible for the course also acted as researchers. During the study sessions, the teachers presented their students' inquiry-based projects and received feedback from other participating teachers, which led to collective reflections on students' thinking and learning. The CPD was followed by research during and after the courses. To investigate whether the course led to lasting changes in the teachers' thinking and practice five of the participating teachers were interviewed about one to two years after they finished the course.

\subsection{Toward science education for all}

"Science education should be an essential component of a learning continuum for all, from pre-school to active engaged citizenship" (European Commission, 2015). Correlating with this and with the European Union's (2006) recommendations for teaching key competencies in the $21^{\text {st }}$ century, seven central competencies are described and focussed on in the curriculum. Inquiry-based learning (see Section 2) is one of the principal elements of the key competency of thinking and learning how to learn (Lonka, 2018). The same competency also is one of the seven key competencies in the national core curriculum launched in Finland in 2016 for first through sixth grades (FNBE, 2016). These competencies are: Thinking and learning to learn; Cultural competence, interaction and self-expression; Taking care of oneself and managing daily life; Multiliteracy; Information and communication technology (ICT) competence; Working life competence and entrepreneurship; Participation, involvement and building a sustainable future (FNBE, 2016). According to Lonka "inquiry-based learning helps the teachers to prepare students for the future challenges of work. In future workplaces, the skills of asking the right questions, defining and solving the most important problems, creating new knowledge, and making changes will be the most crucial requirements." (Lonka, 2018, p. 65).

In first through sixth grades, science, geography and health care are combined into the subject environmental studies. One of the learning goals for environmental studies is students' development of scientific skills. Teachers should guide students to 
communicate their pre-understanding, formulate questions, plan and carry out smallscale research projects based on these questions, described in the core curriculum. (FNBE, 2016). Learning goals include the ability to recognise causal relationships, draw conclusions from research results and, ultimately, present and discuss the results. Primary teachers in Finland usually teach most school subjects, posing challenges regarding teachers' knowledge and understanding of science. The implementation of inquiry-based learning requires changes in classroom practice, as well as a new understanding of science. This understanding includes all three aspects of science: learning science, learning about science (the nature of science) and learning to do science (Hodson, 2014). Science is much more than learning facts, and important learning goals that have been stressed in the Finnish core curriculum is to acquire processing skills and an understanding of them in the context of science (FNBE, 2016).

Recent international studies, e.g., PISA (Organisation for Economic Cooperation and Development [OECD], 2018) and TIMSS 2019 (International Association for the Evaluation of Educational Achievement, IEA, 2019), have shown declining results from Finnish students in science, both in achievement and in motivation and attitudes. Pupils develop their attitudes toward science even before age 11 (Royal Society, 2004), and primary teachers play a central role in shaping these attitudes. Evoking pupils' curiosity about and interest in science and phenomena in the environment is important in science education (DeWitt \& Osborne, 2007). In the Finnish core curriculum, this objective is expressed thusly: "The objective of teaching and learning is to attract and deepen the pupils' interest in various fields of knowledge of environmental studies. ...Problem solving and research assignment are utilised in deepening their interest in phenomena in their surroundings" (FNBE, 2016, p. 257). According to Henriksson (2016), it is not a challenge to arouse interest in science among primary children, but that the primary teachers in her investigation struggled to maintain students' interest as the students aged, and the subject matter became more difficult. Andersson (2008) disagrees with the idea that students' interest is the most important objective in science education. Students' interest, attitudes and process skills are important, but according to Andersson (2008) and Tobin (2006), teachers must raise ambitions and successively take in and use science concepts. Students' interest and motivation can develop concurrently while they acquire content knowledge and do not need to exist first (Berg, Löfgren, \& Eriksson, 2007). 


\subsection{Research objectives and questions}

The first aim of the study is to develop, try out and assess a CPD course model for primary teachers. The CPD course consisted of lectures, workshops, individual mentoring and teachers' implementing IBL with their students. The second aim of the study is to assess the teachers' perceptions of inquiry-based science learning in their own teaching.

Our research questions are:

1. What advantages and challenges did the teachers account for in the continued professional development course model?

2. What were the teachers' perceptions after the CPD concerning inquiry-based learning in primary science?

\section{Theoretical background}

\subsection{Inquiry based learning}

Inquiry-based learning (IBL) in science is a goal, as well as a tool, for learning (Harlen \& Qualter, 2014). The term inquiry in science has been used and understood in many different ways (e.g., Abd-El-Khalick et al., 2004; Anderson, 2007; Crawford, 2014; Lunetta, Hofstein, \& Clough, 2007; Minner, Levy, \& Century, 2010; Rönnebeck, Bernholt, \& Ropohl, 2016). Crawford (2014) interprets teaching science as inquiry as including both the pedagogy and learning outcomes of inquiry in her review article. As Crawford (2014, p. 515) describes it: "... pedagogy being the method of engaging students in designing and carrying out investigations and the learning outcomes referring to learning science subject matter by engaging in these investigations, in addition to learning "about" the nature of scientific inquiry". Inquiry-based teaching and learning describe a spectrum from teacher-led confirmatory inquiry, where students more or less follow a recipe, to open inquiry. In open inquiry, the teacher defines the context while the students formulate their own research questions and different student (groups) conduct different inquiry projects. Between these extremes, lies guided inquiry, where the starting point is the teacher's questions, while the students are given more responsibility to plan and conduct the inquiry. (NRC, 2000). Inquiry is an active learning process in which one learning goal is to learn about the process that, to some extent, can be compared with professional scientists' processes (Anderson, 2002). The process can be described in an inquiry cycle (Figure 1). The 
inquiry circle used is visualised in an article by Elo and Kurtén (2019) and is in line with a model described in Pedaste \& al. (2015). In this study, we use the concept of IBL in line with Anderson's definition, and focus is on guided and open inquiry where a learning goal is the processes of science.

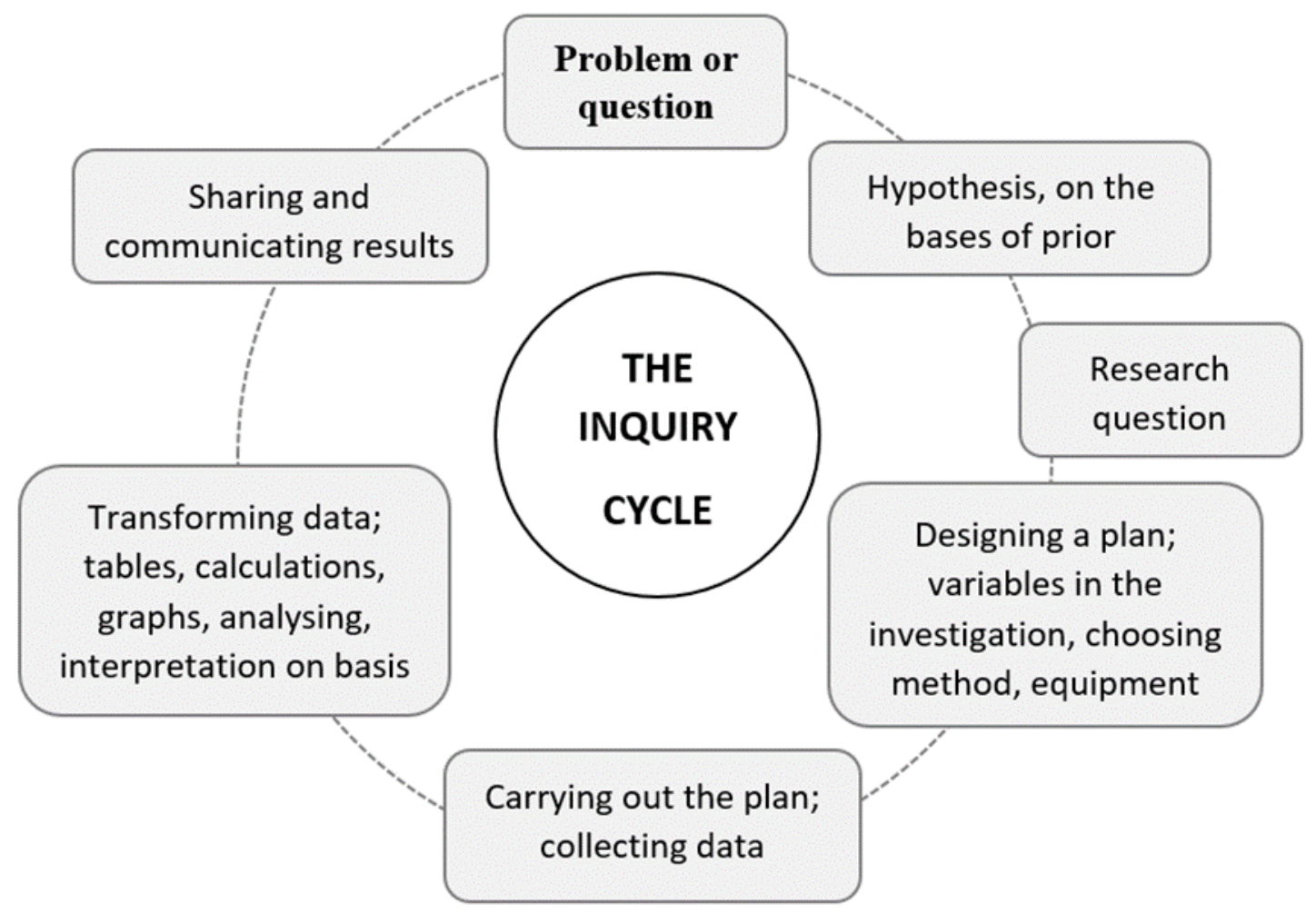

Figure 1. The inquiry cycle (Elo \& Kurtén, 2019).

\subsection{Primary teachers' subject knowledge in science}

A change in how learning is viewed, from an empirical approach to a constructivist approach, has accentuated the need for teachers to develop their teaching (Lederman, Lederman \& Bell, 2004; Skamp, 2011). A constructivist approach entails increased use of student-centred methods, open questions, discussions and group work. For example, the teacher no longer can rely on the textbook (Kikas, 2004). This, in turn, places higher demands on the teacher's subject knowledge, and Harlen and Holroyd (1997) have shown that many primary teachers have insufficient subject knowledge, which can complicate their use of inquiry-based methods in science. Several articles about the Finnish context show that Finnish primary teachers have a lack of subject knowledge in science, knowledge about working methods and about inquiry-based learning (Ahtee \& Johnston, 2006; Herranen \& Aksela, 2013; Palmberg, 2012). 
Researchers also have found that the same misconceptions that students have about science concepts also are present among teacher students and in-service teachers (e.g., Burgoon, Heddle \& Duran, 2011; Härmälä-Braskén, Hemmi, \& Kurtén, 2020; Kikas, 2004; Palmberg et al., 2011; Papageorgiou \& Sakka, 2000; Pine, Messer, \& St. John, 2001; Schoon \& Boone, 1998; Smith, 1997). To be able to challenge pupils to ask questions, scaffold them with relevant resources and assess their understanding in relation to learning goals, primary teachers need basic knowledge and a broad understanding of science.

\subsection{Teacher development}

A skilled teacher integrates successfully subject knowledge with pedagogical knowledge, technological knowledge and knowledge about his students, the core curriculum and the school (e.g., Shulman, 1986; Mishra \& Koehler, 2006). Teachers constantly need to develop their own learning. According to Guskey (2002), teachers will change their perceptions and attitudes if they notice that changes in their teaching positively impact students' learning. Significant educational change comprises changes in beliefs and teaching styles, which can be developed through a process of personal development in a social context. Based on Guskey's model, Clarke and Hollingsworth (2002) developed their interconnected model of professional growth to visualise "the complexity of teacher professional growth through the identification of multiple pathways between the domains" (Clarke \& Hollingsworth, 2002, p. 950), which are personal domain, external domain, domain of practice and domain of consequence. Professional growth also requires that teachers have opportunities to interact with each other, get technical help, and peer support (Fullan, 2016). Teachers are in a key position to effect changes in schools (Hewson, 2007). Their content knowledge is important, but according to Harlen et al. (1997), primary teachers, through in-service training, can get support to develop a deeper understanding of science. They say that teachers need opportunities to discuss their perceptions and develop these together with others.

Professional development can elicit new ways of looking at both the subject, the teaching process and students' learning. Teachers have pedagogical content beliefs that strongly correlate with their teaching and classroom practice (Levitt, 2001). Many reforms have failed because the importance of teachers' beliefs and attitudes has not been considered (Lumpe, Haney, \& Czerniak, 2000). Anderson (2007) points out that professional development should be connected to teachers' own context and 
their own students. When problems arise, teachers should have access to support so they can handle problems.

Appleton (2008) describes how a supervisor, by assuming the role of a mentor and a critical friend, can help primary teachers develop increased pedagogical subject knowledge in science. For a professional development (PD) programme to be fruitful in the long run, according to Levitt (2001), teachers' educational approach should correspond with the individual programme's content and epistemology. In connection with various PD programmes within science education, researchers have found that teachers sometimes follow the programme throughout its duration, and then return to previous working methods when the programme ends (Levitt, 2001). Teachers need time for reflection, as well as support and resources, for professional development. Continued professional development is a prerequisite for teachers' fundamental changes (Appleton, 2008; Forbes \& Skamp, 2014; Levitt, 2001; Peers, Diezmann, \& Watters, 2003). Different teachers have different professionaldevelopment needs. In this vein, the school's headmaster or principal plays a central role (e.g., Lumpe et al., 2012; Fullan, 2016).

\section{The design of the continued professional development}

The CPD course in our study was addressed to primary teachers in first through sixth grades (ages 7-12) who teach environmental science (which includes biology, chemistry, geography, physics and health care). The course consisted of two study sessions, one at the beginning of the course and one concluding part. Between these days, the participants were supposed to complete one-two sequences where they scaffolded their students through guided/open inquiry-based projects in their own class. During this time, the participants also received individual mentoring with regard to their sequences (see Figure 2). The guidance model and the teachers' presentations of their students' projects made it possible for the researchers to follow the participants' development and understanding of IBL. The courses lasted for one year each and were conducted in four different regions of Finland during the 20142017 period, with four different groups of participating teachers. One request concerning participants was that at least two teachers from any one school participate, but this was not a requirement. A total of 34 teachers participated in the course. For various reasons (e.g., parental leave, illness, change of work), eight of the teachers only participated during the first half of the course. These eight teachers did not take part in the final evaluations discussion, nor did they answer the electronic evaluation 
after the course.

The purpose of the CPD course was to help teachers develop their teaching toward open inquiry-based science, while considering students' preconceptions. The focus should be on students' development of their scientific thinking by learning to ask investigative questions, form hypotheses, and plan and conduct their own investigations.

The structure of the CPD course is illustrated in Figure 2. The CPD course started with one day of lectures and workshops (or two afternoons). The participants received electronic material about IBL in advance. The first day focussed on the inquiry cycle (see Figure 1) and children's preconceptions. The inquiry cycle was presented and discussed. The participants worked according to the cycle in a workshop. Other topics presented were how to help students formulate research questions and how to conduct fair tests. At the end of the CPD course, one day was devoted to formative and summative assessment and the use of digital tools in science education. After the first study session, the participants' task was to choose one theme from their ongoing science course. The theme's starting point was that students should use IBL and plan and conduct their own investigations. For implementation, the participants received support in the form of individual mentoring, partly by e-mail and partly from one of the teacher trainers visiting the teacher at his or her own school. During the course, the participants were expected to complete two inquiry-based sequences with their students. During the final study sessions, the participants presented their students' projects and participated in the final evaluation discussion. The teachers answered the electronic evaluation sheet after the completed course. Based on feedback from the third CPD group, a study session was held in the middle of the last CPD course.

The participants were encouraged to keep a diary in which they could reflect on their sequences and their students' learning. However, the participants had difficulty finding the time and motivation to do this. Because of that, the diary element was excluded from the third and fourth CPD groups. 


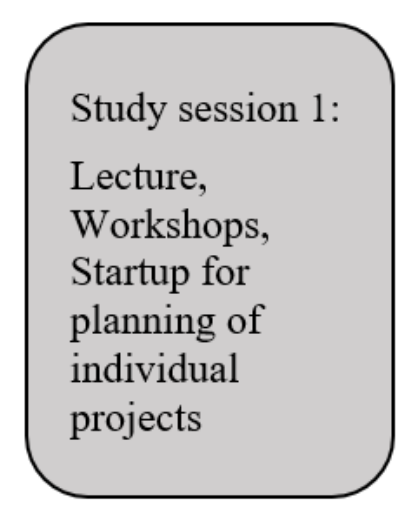

Teachers plan and implement one - two IBL science themes in their classes for students' own projects

Individual mentoring from one of the teacher trainers
Study session 2:

Lecture,

Teachers' presentations of their students' projects and discussion, Evaluation

Figure 2. The structure of the CPD course.

\section{Methods of data collection and analysis}

This qualitative and inductive study investigates a CPD course, in inquiry-based learning in science for primary teachers, in line with the national core curriculum (FNBE, 2016). The CPD course was conducted four times with four different groups of teachers. The research data were collected from all parts in the list below and the analysis is based on all the collected data:

1. Video recordings from four final evaluation discussions (26 teachers in four groups, one after each completed CPD course).

2. The participants' electronic evaluations (open questions) of the CPD $(\mathrm{N}=26)$.

3. The participants' course diaries (from the first and the second CPD course) $(\mathrm{N}=8)$.

4. Recorded semi-structured interviews with five of the participants one to two years after they finished the CPD course $(\mathrm{N}=5)$.

During the final discussions, participants $(\mathrm{N}=26)$ were asked to reflect on the CPD course and on their own implementing IBL with their students within the course. The electronic evaluation form contained ready formulated open questions that the two researchers responsible for the course prepared. The questions concerned the participants' views on the CPD course, their view on teaching science and the role of teacher and student in IBL. Furthermore, the participants were asked whether they 
perceived that the CPD course affected their perceptions about these issues, and if so, in what way. To investigate whether the course made a more permanent impact on the participants' teaching in science, semi-structured interviews with five participants (from three different CPD groups) were carried out one to two years after they completed the course. The interviews took place by phone and were recorded and transcribed.

The data were organised and categorised using NVivo as a software tool. The transcribed and the written material was analysed inductively using two separate models (Braun \& Clarke, 2006; Desimone, 2009). Keywords were identified via repeated reading of the transcribed material, course diaries and the answers from the electronic evaluations. The keywords were used to identify important themes in connection to our research questions.

Braun and Clarke (2006, p. 79) use the following concepts in the thematic analysis: "Data corpus refers to all data collected for a particular research project ... data set refers to all the data from the corpus that are being used for a particular analysis ... data extract refers to an individual coded chunk of data, which has been identified within, and extracted from, a data item." In this research the data corpus of teachers' experiences was analysed thematically on three levels: 1) a data set comprising all instances in which the teachers referred to the research questions; 2) data extracts on a personal level that were analysed and thematically coded; and 3) qualitatively different themes on a general level that were coded. Quotes are used to illustrate these themes' meaning. The analysis for the first research question is based on the participants' statements regarding the different elements and the content of the CPD model. The analysis follows the steps in the model of Braun and Clarke (2006) (see Table 1). 
Table 1. Subthemes and themes created and used in the analysis of the collected data (video recordings, evaluation discussion, electronic evaluations, course diaries and semi-structured interviews) for the first research question.

\begin{tabular}{|c|c|c|}
\hline $\begin{array}{l}\text { Initial codes (The } \\
\text { different elements } \\
\text { of the CPD) }\end{array}$ & Subthemes & $\begin{array}{l}\text { Themes } \\
\text { ADVANTAGE (A) } \\
\text { CHALLENGE (C) }\end{array}$ \\
\hline \multirow[t]{2}{*}{ Study sessions } & $\begin{array}{l}\text { Lectures and workshops: inspiration, } \\
\text { insight in inquiry-based learning and in } \\
\text { research in science education, practical } \\
\text { skills }\end{array}$ & $\begin{array}{l}\text { (A) Impact on participants' knowledge, } \\
\text { attitudes and skills }\end{array}$ \\
\hline & New ideas from other participants. & (A) Collegial learning \\
\hline \multirow[t]{2}{*}{ Personal coaching } & $\begin{array}{l}\text { Personal help by the teacher trainer at } \\
\text { my own school, help with equipment and } \\
\text { material }\end{array}$ & $\begin{array}{l}\text { (A) Impact on participants' courage to } \\
\text { test IBL }\end{array}$ \\
\hline & $\begin{array}{l}\text { Difficult to let go of old ways of thinking } \\
\text { and acting }\end{array}$ & (C) To change one's mindset \\
\hline \multirow[t]{4}{*}{$\begin{array}{l}\text { Teachers' own } \\
\text { planning and } \\
\text { implementation }\end{array}$} & $\begin{array}{l}\text { The requirement that you had to } \\
\text { implement IBL in your own class -> you } \\
\text { immerse yourself more, you challenge } \\
\text { yourself }\end{array}$ & $\begin{array}{l}\text { (A) Satisfaction of having completed } \\
\text { projects }\end{array}$ \\
\hline & $\begin{array}{l}\text { Got to work with your own class with } \\
\text { your own themes }\end{array}$ & (A) Flexibility in the course \\
\hline & $\begin{array}{l}\text { Completed models would be less time } \\
\text { consuming }\end{array}$ & (C) Time for the projects \\
\hline & Limit the projects in your class & \\
\hline \multirow{2}{*}{$\begin{array}{l}\text { Facebook / } \\
\text { Cooperation with } \\
\text { other participants }\end{array}$} & $\begin{array}{l}\text { A strength to be two from the same } \\
\text { school }\end{array}$ & $\begin{array}{l}\text { (A) Collaboration between teachers } \\
\text { from the same school }\end{array}$ \\
\hline & FB: no sharing of questions, ideas & $\begin{array}{l}\text { (C) Teachers not used to sharing } \\
\text { material: do not think what they have } \\
\text { is good enough to share }\end{array}$ \\
\hline \multirow[t]{2}{*}{ The whole course } & $\begin{array}{l}\text { Gave development ideas and started a } \\
\text { process } \\
\text { The CPD as a whole is a maturation } \\
\text { process }\end{array}$ & $\begin{array}{l}\text { (A) Starting point for a own reflections } \\
\text { of one's teaching and a new mindset }\end{array}$ \\
\hline & $\begin{array}{l}\text { Asking questions without ready-made } \\
\text { answers }\end{array}$ & (C) Sense of limited subject knowledge \\
\hline
\end{tabular}


For the analysis regarding research question two concerning teachers' perceptions on IBL we have used the model of Desimone (2009) (Figure 3). The outcome of the analysis is visualised in Figure 4 and discussed against the backdrop of previous research in section 6 . The participating teachers' statements regarding IBL are analysed thematically to find qualitatively different themes on a more general level. The results from the analysis are collected in Figure 4.

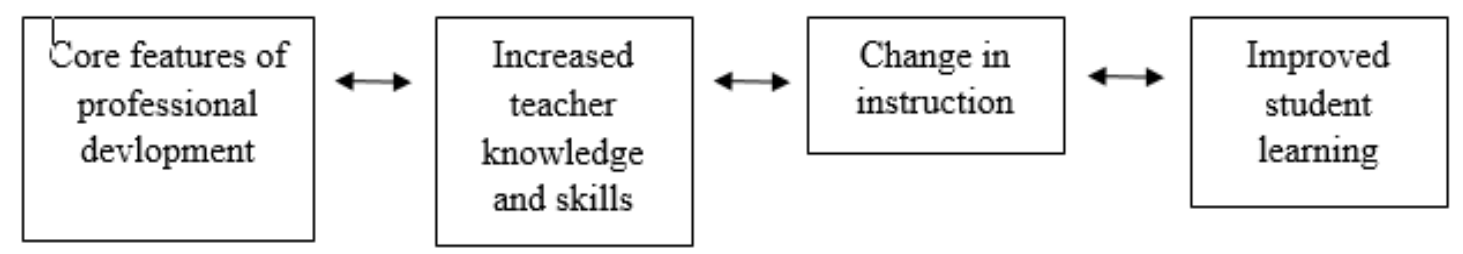

Figure 3. 'Proposed core conceptual framework for studying the effects of professional development on teachers and students' (Desimone, 2009, p. 185).

\begin{tabular}{|l|}
\hline $\begin{array}{l}\text { Core features of professional } \\
\text { development }\end{array}$ \\
Focus on inquiry-based science \\
Active learning: \\
1. Workshops about the \\
inquiry-based science \\
2. Individual coaching of the \\
teachers by the teacher \\
trainer \\
3. Implementing project in \\
own class \\
4. Presentations of projects in \\
the CPD-group \\
Duration: The CPD extended \\
over a year \\
Collective participation: \\
It was desired that at least two \\
teacher from the same school \\
should attend the course
\end{tabular}

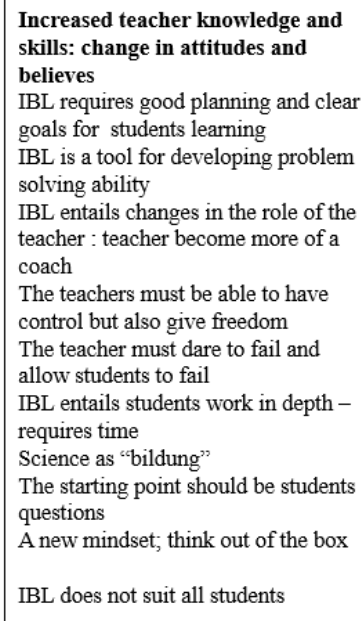

IBL does not suit all students

Changes in instruction (after
the course)
Teachers' aims
(questionnaire within some
weeks after the course):
Clear hopes of allowing
students engage in IBL.
Working inquiry-based is in
line with the curriculum, 2015
Concern for practically getting
it and for lack of own
knowledge
5 teachers interviewed one to
two years after the course:
All of these 5 teachers use
some form of IBL
Learned to limit the projects
and focus on the essentials
Start from the students'
knowledge and skills

Figure 4. Results analysed and presented according to a modified version of a model of Desimone (2009).

The analysis was carried out in collaboration between the two researchers. The interpretations of the participants' comments in the evaluation discussions, diaries, interviews and in their responses to the questionnaire were discussed until a consensus was reached. The categories were iteratively developed and refined in a shared meaning-making process. The use of several data sources gave a broad basis for the analysis. Through the individual mentoring of the participating teachers in the CPD course, we got a close contact to these, which was important for the collection 
and interpretation of data. Our own long-term experience, as teachers in primary school and/or secondary school and within in-service teacher education, were valuable in the interpretation of the teachers' reflections. The fact that the researchers had a close relationship with the context is an advantage. According to Dalen (2007), the ideal is that the researcher can achieve a so-called Picasso profile, i.e. that the researcher is both inside and outside the research profile at the same time. Kvale (1997) states that the researcher's knowledge of the subject is a prerequisite for a valid interpretation. In reporting the results, we offer authentic extracts from the participants to make our analysis transparent. The aim of the study is to find and present critical features in the CPD model and in implementing IBL in science education, to consider for comparison with other similar cases.

\section{Results}

The outline in this section is based on the two research questions. The subtitles in section 5.1 relate to the advantages and challenges that the teachers identified in the CPD course, while the subtitles in section 5.2 are based on the results concerning teachers' views of IBL, compiled in Figure 4.

\subsection{What advantages and challenges do the teachers account for in the continued professional development model?}

\section{Advantages with the CPD model}

The study sessions with lectures, in combination with practical exercises, were valuable, according to many participants. One participant highlighted the link to research and the educational structure, as teachers usually have neither the time, nor the opportunity, to immerse themselves in current research: "I value the research and methods shared by the teacher trainers. The course has not only been about education; it had an educational structure, and that was valuable." The study sessions also instilled inspiration and courage to try new things. An important part of the sessions was the opportunity to take part in and reflect on other participants' presentations of their students' projects. This gave the participants new ideas for their own teaching. For example, two teachers working in the same school shared the experience of having he students make cartoons of a theme that they worked on. The cartoons were then used in the assessment of the students' work. This inspired other participants in the group. The participants served as sounding boards when they took 
part in the other teachers' presentations, and at the same time, they contributed to each other's development.

The individual mentoring that the participants received when developing their teaching sequences was important, according to the participants. This mentoring, that the teachers received, helped the teachers with both ideas and materials, and encouraged them to carry out their sequences: "The advisory coaching gave the support I needed to plan my project." The tutoring also elicited an affective effect: "Absolutely wonderful that someone takes time to help me, find electronic links and so on." At the same time, the guidance was not perceived as controlling: "You are pushed forward, but still you plan your own projects and develop your own thoughts." After the course, many participants expressed their satisfaction with their own efforts and sequences. The set-up in which the participating teachers should implement IBL, which was in focus during the first workshop day, was viewed as important:

It is valuable when you, right away, must try out the new thoughts and ideas. To get supervision and help with materials at the same time is valuable. In this way, I think that the CPD also has a ripple effect and gives a lasting result.

The CPD course was, in this way, anchored to the teachers' own teaching, which was viewed as a basis for leading to lasting changes in their own teaching. When the participants had to plan and implement science as inquiry in their own teaching as part of the course, they developed a better understanding of inquiry learning. The struggle with a new way of teaching and experiencing success provided positive feelings and satisfaction.

In the invitation to the course, it was recommended that two or more teachers from the same school attend the course. Teachers who were from the same school highlighted this as being valuable in their evaluation: "I am grateful for having a colleague on the same course. We have been able to discuss our thoughts about and our reflections on the course content." Most participants did not have colleagues from their schools attending with them.

The course was carried out four times in different regions of Finland. Because of this, the number of participants in each region was relatively small (7-12 teachers). This was viewed as important: "It was good that we were not so many ... everybody became more active when it's a smaller group." The fact that the course lasted a long time and was not just a one-day course was viewed as significant: "You need this time to think and reflect." The number of study sessions also was viewed as appropriate. Too many sessions might have been discouraging and might have prevented the 
teachers from participating in the course. A longer-lasting course like this was also perceived as eliciting a more permanent effect on their own teaching.

Among comments after the course, some said it opened up new ways of thinking, built courage and opportunities to try new teaching methods or opened their eyes to teaching science in a manner that interests the students.

\section{Challenges with the CPD course}

Primary teachers' lack of time and fragmented daily work were problematic factors, according to the participating teachers in the CPD course. The teachers felt that they had neither the time nor the opportunity to focus on developing their inquiry-based sequences in their own classes as much as they wanted: "External factors ... time does not stop ... other factors continue with undiminished strength even though I would like to concentrate on this."

One challenge was to limit the students' own projects and prevent them from becoming too extensive and time-consuming. One of the teachers who carried out two inquiry-based sequences in her class during the CPD course noted that this gave her the opportunity to gain experience from the first sequence and make improvements on the second: "I'm pleased with my second project because it was more limited. The first one was very (educational) for me with many attempts and mistakes. It is important to limit!" To make IBL implementation more feasible and less time consuming, one participant suggested that there could be ready-made models.

One part of the course involved the participants' own reflections on their own development during the course, recorded in a course diary. This turned out to be difficult to implement, mainly due to lack of time, but also due to lack of motivation. As course leaders, we had not succeeded in communicating the diary's purpose.

From the start of the CPD, the hope was that the participants would collaborate with each other, share their ideas and keep in touch with each other. To facilitate this, a Facebook group was created for every separate course. The participants also had access to each other's e-mail addresses. However, these tools were never used that often. The sharing of ideas was limited to the study sessions, when participants met with each other, except for those teachers who could cooperate within their own schools. One participant suggested that it perhaps would have been better if teachers from different schools had chosen the same themes for their sequences. It turns out that even when some teachers had chosen the same themes, they did not cooperate. A comment about the lack of cooperation was that teachers in the Finnish culture do not 
ask for help, and they do not believe that their own work is good enough to share with others.

\subsection{What were the teachers' perceptions after the CPD concerning inquiry-based learning in primary science?}

Increased teacher knowledge and skills: change in attitudes and beliefs

Several participants in the CPD said IBL in science requires that the teacher do much planning and possess good subject knowledge: "The teacher should have an 'iron grip' on the subject!" Well-thought-out planning, in which the teacher has clear goals for the students' learning, is a prerequisite for students' work in formulating researchable questions, then planning and conducting their own investigations: "To open up the task for the students without giving them total freedom." However, the teacher simultaneously should have the courage to relinquish control when students work with their own questions.

The teacher has an important role as the person who can awaken students' curiosity and interest: "It's easy to kill the students' interest from the first minute if the introduction is boring." One teacher commented on the fact that teachers most often answer questions that nobody has asked, but students are interested in getting answers to their own questions.

One teacher highlighted the problem of coping with all the core curriculum content when students use IBL. Another teacher emphasised the importance of teaching in depth and allotting time for this: "The most important is not to cover much, but to do thoroughly what you do." Many teachers highlighted their own perception of lack of time for planning, collaborating and reflecting.

Many of the participants perceived that IBL involves a change in the teacher's role. The teacher's task is to inspire, but also to act as a coach. For a teacher, it is challenging to have the courage to relinquish control and believe in the students' ability to learn, i.e., to believe that students will learn even if you, as the teacher, do not present everything to them. One teacher also stressed that he had developed more courage to relinquish control and make mistakes. It is acceptable to arrive at different solutions and different answers. In addition to being responsible for learning goals, the teacher is responsible for assessing students. The participants emphasised formative assessment as an assessment of the processes and of students' work with their projects. However, this assessment method was viewed as challenging and time consuming. 
Improved students' learning: Teachers view

Many of the teachers in the CPD course stressed the affective factors that they observed when the students used IBL: "They work with joy and enthusiasm"; "I start to realise how fun the students think it is to investigate on their own"; "I think that students are more motivated when they work inquiry-based"; "It engages". However, the participants also emphasised students' learning and how it affects these when they studied according to IBL. One of the teachers highlighted the importance of students' previous knowledge and experience emerging when they use IBL: "Students learn when they can influence their learning situation on the basis of their own knowledge and experiences, which they do when they work inquiry-based." The importance of student participation, responsibility and activity was emphasised: "The students should be more active in the planning, in setting goals and in the assessment." IBL also entails that the students must take greater responsibility for their work and develop collaborative skills when working in a group. According to teachers, it is important that the students feel like they are allowed to make mistakes and learn from them.

Some participants pointed out that IBL is not appropriate for all students and that not all students like this method of working: "Many students can work in this way, but for some of them, it is hard and challenging." One of the teachers saw the challenge of getting the students interested in learning for their own sake, not just because they must achieve for the teacher's sake.

Although the teachers viewed IBL as a way of teaching in which students take more responsibility and learn more independently, they also stressed the importance of guidance and support from the teacher. One teacher pointed out that IBL requires time to learn and that as a teacher; you should approach it in small steps. She thought that it might be easier if the students learned IBL in their early years in school.

\section{Changes in instruction}

Looking ahead, what did the participants think about their science teaching after the course? Would the CPD course have a lasting impact on their teaching? Teachers' comments show some changes in their thinking: "The course reopened my eyes, and I had the opportunity to reflect on my working methods"; "I have seen opportunities"; "I have already noticed that I change my way of teaching to get the students to solve problems and investigate more"; "I do not serve everything". However, on the question of what impact the course would have on their future teaching, the 
participants remained cautious. Formulations like "I think I will", "I aim for", "I hope" and "I try" dominated the answers when asked about letting students use IBL. There were clear hopes, as well as insights into difficulties in terms of lack of time, stress, dividing up time for countless other tasks and shortcomings in their own knowledge. The teachers also saw difficulties in breaking their old patterns and changing their mindset. A mindset can affect what changes will be made and how big they will be. However, the teachers clearly saw that IBL was in line with the core curriculum, and they saw opportunities in this method of learning. IBL was an eye-opener for one teacher, who reflected on its benefits with science learning:

It is interesting to wonder about things around us. It is important not only from national economic aspects (which are often emphasised), but as rewarding for the individuals, in a way that is difficult to measure, like all 'bildung'.

Semi-structured interviews were conducted one or two years after the CPD course with five of the attending teachers from three separate CPD groups. The purpose of these interviews was to investigate what perceptions these teachers have about teaching science after the course and what possible effects the course exerted on their teaching and attitudes.

All five teachers said they use IBL in some form in their teaching. According to all these teachers, a coherence exists between the national core curriculum's objectives and IBL. The teachers feel that the CPD course gave them an increased awareness about their teaching: "What questions should you start from?"; "Should the students find out more themselves?" According to one of the interviewed teachers, the most important thing that stuck in his mind is that the course gave him a new mindset. He feels that he has been able to free himself from old, inward models so that he can, as he expresses it, "think outside the box".

While working with various inquiry-based projects in their classes after the CPD course, the teachers gradually learned to limit the projects and focus on more relevant aspects. One teacher says that she now starts from the students' prior knowledge and competence levels in her teaching. The ability to solve problems of various kinds, individually or together with others, is described by another teacher as a competency that the students will need in different societal contexts. He sees IBL as a tool to help students develop problem-solving competencies. The importance of teachers having a firm grasp of subject knowledge, being well-prepared and linking projects to scientific concepts is emphasised. 


\section{Discussion and conclusions}

\subsection{Core features of the professional development model and teacher growth}

Central in the CPD course was the connection between the theory and the themes that were addressed during the workshops and the teachers' own implementation of them in their own science teaching practice. Garet et al. (2001, pp. 925-926) stress the importance of teachers' active learning that "involves the opportunity to link the ideas introduced during professional development experiences to the teaching context in which teachers work." Participants experienced the study sessions as being important to gain theoretical knowledge of IBL and increase subject knowledge. The teachers also gained insight into current research in the field about e.g. children's preconceptions in science, the inquiry cycle and formative assessment. The teachers felt that they normally had neither the time nor the opportunity to take part in current research. Teacher trainers gave the teachers individual mentoring at their own schools. The teachers deemed this as being very important (cf. Kleickmann et al., 2015). The guidance that the teachers received encouraged them to develop and carry out their own sequences. The teachers did not receive any ready-made teaching materials. Instead, they had to design their IBL teaching sequences by themselves. For the trainer, it was challenging to find a balance in supervising, but not dictating, what each teacher should do (cf. Bjønnes \& Kolstø, 2015). The same challenge applies to the teacher in teaching situations in which students are involved in IBL. This supervision situation can provide the teacher with a model for these situations (cf. van der Valk \& de Jong, 2009).

This study's results confirm previous research (e.g., Garet et al., 2001; Peers, Diezmann \& Watters, 2003; Desimone, 2009) that found longitudinal CPD courses provide teachers with opportunities to reflect on their own learning and develop sequences where student work with own IBL projects. The course in this study provided the participants with opportunities to discuss ideas with other course participants during the study sessions, which was viewed as important. If they took the course with colleagues from their school, the teachers continually could discuss and develop their sequences in relation to course content between study sessions. The participants who had colleagues from the same school highlighted the advantage of this. The significance of collaboration with colleagues also is stressed in previous research (Garet et al., 2001; Desimone, 2009; van der Valk \& de Jong, 2009). 


\subsection{Implementing IBL - teachers' views}

The teachers in this study expressed agreed that IBL entails new roles for both the teachers and the students, requiring time for reflection and for maturing into these roles (cf. Fullan, 2016; Åhman, Gunnarsson \& Edfors, 2015). The role of the teacher becomes more that of a coach than a knowledge communicator. This entails challenges for teachers regarding their view of their own teaching role, learning goals for the students and the students' responsibilities in the learning process.

Teachers in the study emphasised the importance of having their own control over their teaching, clear goals for students' learning and a well-thought-out plan when students work inquiry-based (cf. Hodson, 2009; Smith et al., 2012). At the same time, the teachers saw the importance of the students working with their own questions, which means that they, as teachers, must have the courage to let go of some of their control. This is in line with what van der Valk and de Jong (2009) discuss as giving the students structure as well as space. Teachers who are accustomed to following a textbook may find it difficult to free themselves from the teaching pattern they usually use.

IBL is about having the courage to believe that students learn, even if the teacher does not "present everything to them"; it is about having the courage to open up to questions without having the answer. As the teacher, you must dare to work outside your comfort zone. The need for deep subject knowledge was highlighted. Our interpretation is that when you feel secure in your own subject knowledge, you feel safer to let your students engage in questions you do not have direct answers. The teacher's coaching and scaffolding role is important (Furtak et al., 2012). This way of working is new for many teachers. According to the teachers in the study, IBL requires time to learn and as a teacher, one should approach it in small steps.

The teacher's view of the subject itself and what is important for students to learn is also challenged when working more student-centered with IBL. While one teacher saw the problem of "coping with all the curriculum content" when students use IBL, another emphasised the importance of "doing thoroughly what you do". Letting students start from their own prior knowledge with questions that they formulate themselves takes more time than traditional teacher-centered instruction where the teacher follows the textbook. It is perhaps easy to forget that the objectives in the core curriculum consist not only of content knowledge but also of research and working skills (FNBE, 2016). These can be learnt by doing inquiry-based science. 
A new insight and a new mindset in teachers after the course was expressed by one participant: "Science is about thinking outside the box and it means much more than factual knowledge." Another participant expressed her new insight "Science is about bildung”, which is in line with the European Commission report (2015).

\subsection{Teachers' views of students' learning with IBL}

During the CPD there was an ongoing reflection and discussion within the group of teachers about how IBL affects different aspects of students' learning. Particular factors that emerged are the need to achieve deep learning by giving students enough time to work with their projects. Deep learning, which is about thinking and understanding, must according to Fullan (2016) be developed if one is to understand the world. One challenge that teachers highlighted was their own fragmented work picture and the perception that IBL takes more time than traditional teaching. The teachers were worried about not having enough time for teaching the subject matter. Van Aalderen-Smeets and Walma van der Molen (2015, p. 711) argue that "science should be taught as the process of acquiring scientific knowledge (inquiry-based learning approach) and should stimulate an understanding about the nature of scientific inquiry, rather than teaching science as a body of knowledge".

National (FNBE, 2016) and international steering documents (European Commission, 2015) stipulate that students shall develop their problem-solving skills and collaborative skills, among others. The teachers highlight both of these skills in the study as skills that the students develop by working with IBL. Several of the participating teachers also described IBL as motivators for students, exerting a positive influence on their learning (cf. Kurtén-Finnäs, 2008). According to the teachers, students felt that they could influence their own learning situation. The students' interest and motivation, in turn, inspired the teachers to continue to use IBL.

However, according to the teachers, IBL does not work with all students, though the teachers did not specify which group of pupils they were talking about. Research on the use of IBL and students with learning disabilities shows that investigative work makes a positive impact on the students' understanding, as well as on their scientific attitudes and their attitudes toward the subject (e.g., Aydeniz et al., 2012). A potential group that is negative toward IBL might be students who want clear instructions, as well as structured teaching. Eysink, Gersen and Gijlers (2015) have examined talented students who work with both structured inquiry and unstructured inquiry. Their 
results show that the gifted students experienced a lack of control of the task when it was unstructured. For them, it was important to get some guidance during the process. For teachers who have no or very little experiences of inquiry-based teaching, it can be difficult to know how much guidance they should give students when they are working inquiry-based.

\subsection{Teachers' changes in instruction}

IBL, as a working method, is entirely in line with intentions in the national core curriculum (FNBE, 2016). Immediately after the CPD course, the teachers had clear hopes of implementing IBL in their teaching. Simultaneously, concerns arose over lack of time, positioning of teacher-student roles and the ability to work toward learning goals without dictating what the students must do. There was also a fear that their own subject knowledge was insufficient.

Teachers who were interviewed one or two years afterwards completing the course stated that they use IBL in some way in their own teaching. They have learned to limit the sequences and the students' projects and focus on the essentials. They also stated that they now approach teaching based on students' knowledge and skills.

The model of a CPD course in which theoretical input, scaffolding, practical work and educational reflections are combined appears to result in positive changes in teacher instruction and, by extension, hopefully in students' science learning.

\subsection{Critical reflections}

Each CPD course ended with an evaluation discussion that was recorded. In this way, each teacher's thoughts about the course and the use of IBL in their teaching were collected. Teachers' diaries would have provided even more information about their thoughts during the course. For the continuous formative follow-up, some other type of tool for reflecting and reporting could have been used. The tool should be one that teachers experience as less work-intensive. For the researchers, this means a balance between exposing the teachers to extra work and collecting important information. Despite the fact that the teachers' diary entries became few, these still contributed to the information becoming more versatile.

The teachers who participated in the course volunteered to participate and were motivated. To introduce and implement the same programme for all the teachers in one school would be more challenging. The teachers who participated in the CPD course were interested in teaching science. They wanted to develop their subject 
knowledge and their pedagogical competence within the subject. For teachers who lack personal motivation, more personal guidance is needed, which involves guidance on subject knowledge as well as on IBL.

Only five teachers who participated in the CPD course were interviewed in the study, between one and two years after. Interviews with all participating teachers would have given more information about the long-term impact on their teaching.

\subsection{Implications}

In the future a CPD course about IBL could be directed toward all teachers within a school. IBL in Science education fits well into interdisciplinary themes where e.g. aspects from biology, physics and chemistry can be investigated. A new CPD course about IBL could be directed toward all science teachers within a school. This would create more opportunities for discussion between teachers. Such a CPD course about IBL, which is aimed at an entire teacher group, also presupposes that the principal of the school is familiar with the CPD's objectives and supports the teachers in the developmental work that the CPD entails. According to Fullan (2016), the principal is in a key position concerning teachers' professional development and development of the school community. In the Finnish school context the principals, parallel to the administrative leadership, also have the responsibility of being educational leaders. This demands that the principals are familiar with current educational research and with various opportunities for teacher development.

\section{Acknowledgements}

We would like to thank Stiftelsen Brita Maria Renlunds minne for its financial contribution to the developmental work with and implementation of the CPD course.

\section{References}

Abd-El-Khalick, F., Boujaoude, S., Duschl, R., Lederman, N. G., Mamlok, R., Hofstein A., Niaz, M., Treagust, D., \& Tuan, H-L. (2004). Inquiry in science: International perspectives. Science Education, 88(3), 397-400. https://doi.org/10.1002/sce.10118

Ahtee, M. \& Johnston, J. (2006). Primary student teachers' ideas about teaching a physics topic. Scandinavian Journal of Educational Research 5O(2), 207-219. https://doi.org/10.1080/00313830600576021

Anderson, R. D. (2002). Reforming Science teaching: What research says about inquiry. Journal of Science Teacher Education, 13(1), 1-12. https://doi.org/10.1023/A:1015171124982 
Anderson, R. D. (2007). Inquiry as an organising theme for science curricula. In: S. A. Abell \& N. G. Lederman (Eds.), Handbook of research on science education (pp. 807-830). Mahwah, New Jersey: IEA.

Andersson, B. (2008). Grundskolans naturvetenskap - helhetssyn, innehåll och progression. Lund, Sweden: Studentlitteratur.

Appleton, K. (2008). Developing science pedagogical content knowledge through mentoring elementary teachers. Journal of Science Teacher Education, 19(6), 523-545. https://doi.org/10.1007/s10972-008-9109-4

Aydeniz, M., Cihak, D. F., Graham, S. C., \& Retinger, L. (2012). Using inquiry-based instruction for teaching science students with learning disabilities. International Journal of Special Education, 27(2), 189-206.

Berg, A., Löfgren, R., \& Eriksson, I. (2007). Kemïnnehåll i undervisningen för nybörjare. En studie av hur ämnesinnehållet får konkurrera med målet att få eleverna intresserade av naturvetenskap. NorDiNa, 3(2), 146-162. http://dx.doi.org/10.5617/nordina.377

Bjønnes, B., \& Kolstø, S. D. (2015). Scaffolding open inquiry: How a teacher provides students with structure and space. NorDiNa, 11(3), 223-237. http://dx.doi.org/10.5617/nordina.878

Braun, V., \& Clarke, V. (2006). Using thematic analysis in psychology. Qualitative Research in Psychology, 3(2), 77-101. https://doi.org/10.1191/1478088706qpo63oa

Burgoon, J. N., Heddle, M. L., \& Duran, E. (2011). Re-examining the similarities between teacher and student conceptions about physical science. Journal of Science Teacher Education, 22(2), 101-114. https://doi.org/10.1007/s10972-010-9196-x.

Clarke, D., \& Hollingsworth, H. (2002). Elaborating a model of teacher professional growth. Teaching and Teacher Education, 18(8), 947-967. https://doi.org/10.1016/So742051X(02)00053-7

Crawford, B. A. (2014). From inquiry to scientific practices in the science classroom. In: N. G. Lederman \& S. A. Abell (Eds.), Handbook of Research on Science Education (pp. 515-541). New York: Routledge.

Dalen, M. (2007). Intervju som metod. Malmö: Gleerups.

Desimone, L. M. (2009). Improving impact studies of teachers' professional development: Toward better conceptualisations and measures. Educational Researcher, 38(3), 181-199.

https://doi.org/10.3102/0013189X08331140

DeWitt, J., \& Osborne, J. (2007). Supporting teachers on science-focussed school trips: Towards an integrated framework of theory and practice, International Journal of Science Education, 29(6), 685-710. https://doi.org/10.1080/09500690600802254

Elo, J. \& Kurtén, B. (2019). Exploring points of contact between enterprice education and openended investigations in science education. Education inquiry, 11(1), 18-35.

https://doi.org/10.1080/20004508.2019.1633903

European Commission (2015). Science education for responsible citizenship. Report to the European Commission of the expert group on science education.

http://ec.europa.eu/research/swafs/pdf/pub_science_education/KI-NA-26-893-EN-N.pdf

European Union (2006). European Union's recommendation on key competences for lifelong learning. http://eur-lex.europa.eu/legal-content/EN/TXT/?uri=celex:32006Ho962

Eysink, T.H.S., Gerson L. \& Gijlers, H. (2015). Inquiry learning for gifted children. High Ability Studies, 26(1), 63-74. https://doi.org/10.1080/13598139.2015.1038379

Finnish National Board of Education (2016). National core curriculum for basic education 2014. Helsinki, Finland: Next Print Oy. 
Forbes, A., \& Skamp, K. (2014). 'Because we weren't actually teaching them, we thought they weren't learning': Primary teacher perspectives from the MyScience Initiative. Research in Science Education, 44(1), 1-25. https://doi.org/10.1007/s11165-013-9367-9

Fullan, M. (2016). The new meaning of educational research. London: Routledge.

Furtak, E. M., Seidel, T., Iverson, H. \& Briggs, D. C. (2012). Experimental and quasi-experimental studies of inquiry-based science teaching: A meta-analysis. Review of Educational Research, 82(3), 300-329. https://doi.org/10.3102/0034654312457206

Garet, M. S., Porter, A. C., Desimone, L., Birman, B. F., \& Suk Yoon, K. (2001). What makes professional development effective? Results from a national sample of teachers. American Educational Research Journal, 38(4), 915-945. https://doi.org/10.3102/00028312038004915

Guskey, T. R. (2002). Professional development and teacher change. Teachers and Teaching: Theory and Practice, 8(3/4), 381-391. https://doi.org/10.1080/135406002100000512

Harlen, W. (1997). Primary teachers' understanding in science and its impact in the classroom. Research in Science Education, 27(3), 323-337. https://doi.org/10.1007/BF02461757

Harlen, W., \& Holroyd, C. (1997). Primary teachers' understanding of concepts of science: Impact on confidence and teaching. International Journal of Science Education, 19(1), 93-105. https://doi.org/10.1080/0950069970190107

Harlen, W., \& Qualter, A. (2014). The teaching of science in primary schools. London: Routledge. Henriksson, A-C. (2016). Man måste tänka själv: klasslärares uppfattningar av undervisning $i$ de naturvetenskapliga läroämnena. [You have to think for yourself: primary teachers' perceptions of teaching science]. Doctoral thesis. Åbo Akademi University.

Herranen, J. \& Aksela, M. (2013). Täydennyskoulutus luokanopettajien kemian opetuksen tukena. (Professional development for primary teachers supporting their teaching of chemistry.) LUMAT 1(4), 323 - 328. https://journals.helsinki.fi/lumat/article/view/1090

Hewson, P. W. (2007). Teacher professional development in science. In: S. K. Abell \& N. G. Lederman (Eds.), Handbook of research on science education (pp. 1179-1203). Mahwah, New Jersey: IEA.

Hodson, D. (2009). Teaching and learning about science: Language, theories, methods, history, traditions and values. Rotterdam, Netherlands: Sense Publishers.

Hodson, D. (2014). Learning science, learning about science, doing science: Different goals demand different learning methods. International Journal of Science Education, 36(15), 2534-2553 https://doi.org/10.1080/09500693.2014.899722

Härmälä-Braskén, A-S., Hemmi, K., Kurtén, B. (2020). Misconceptions among Finnish prospective primary school teachers - a long-term study. International Journal of Science Education 42(9), 1447-1464. https://doi.org/10.1080/09500693.2020.1765046

IEA (2019). TIMSS 2019. International results in mathematics and science. https://timssandpirls.bc.edu/timss2019/international-results/wpcontent/themes/timssandpirls/download-center/TIMSS-2019-International-Results-inMathematics-and-Science.pdf

Kikas, E. (2004). Teachers' conceptions and misconceptions concerning three natural phenomena. Journal of Research in Science Teaching, 41(5), 432-448. https://doi.org/10.1002/tea.20012

Kleickmann, T., Tröbst, S., Jonen, A., Vehmeyer, J., \& Möller, K. (2015). The effects of expert scaffolding in elementary science professional development on teachers' beliefs and motivations, instructional practices and student achievement. Journal of Educational Psychology, 108(1), 21-42. http://dx.doi.org/10.1037/eduooooo41

Kurtén-Finnäs, B. (2008). Det var intressant, man måste tänka så mycket. Öppna laborationer och $V$-diagram i kemiundervisningen. [It was interesting; you had to think so much. Open- 
ended investigations and V-diagram in chemistry education]. Doctoral Thesis. Vasa: Åbo Akademi University.

Kvale, S. (1997). Den kvalitativa forskningsintervjun. Lund: Studentlitteratur.

Lederman, N.G., Lederman, J.S. \& Bell, R. L. (2004). Constructing Science in Elementary Classrooms. Boston: Pearson Education Inc.

Levitt, K. E. (2001). An analysis of elementary teachers' beliefs regarding the teaching and learning of science. Science Education, 86(1), 1-22. https://doi.org/10.1002/sce.1042

Lonka, Kirsti (2018). Phenomenal learning from Finland. Helsinki, Finland: Edita.

Lumpe, A. T., Czerniak, C. M., Haney, J. J., \& Beltyukova, S. (2012) Beliefs about teaching science: The relationship between elementary teachers' participation in professional development and student achievement. International Journal of Science Education, 34(2), 153-166. https://doi.org/10.1080/09500693.2010.551222

Lumpe, A. T., Haney, J. J., \& Czerniak, C. M. (2000). Assessing teachers' beliefs about their science teaching context. Journal of Research in Science Teaching, 37(3), 275-292. https://doi.org/10.1002/(SICI)1098-2736(200003)37:3<275::AID-TEA4>3.0.CO;2-2

Lunetta, V. N., Hofstein, A., \& Clough, M. P. (2007). Learning and teaching in school science laboratory: An analysis of research, theory and practice. In: S. A. Abell \& N. G. Lederman (Eds.), Handbook of research on science education, (pp. 393-442). Mahwah, New Jersey: IEA.

Minner, D. D., Levy, A. J., \& Century, J. (2010). Inquiry-based science Instruction - What is it and does it matter? Results from a research synthesis years 1984 to 2002. Journal of Research in Science Teaching, 47(4), 474-496. https://doi.org/10.1002/tea.20347

Mishra, P., \& Koehler, M. J. (2006). Technological pedagogical content knowledge: A framework for integrating technology in teachers' knowledge. Teachers College Record, 108(6), 10171054 .

National Research Council (NRC). (2000). Inquiry and the National Science education Standards. Washington, D.C: National Academy Press.

Organisation for Economic Cooperation and Development (OECD) (2018). Pisa 2015: Results in Focus. https://www.oecd.org/pisa/pisa-2015-results-in-focus.pdf

Palmberg, I. (2012). Artkunskap och intresse för arter hos blivande lärare för grundskolan. "Student teachers' knowledge of and interest in species" . NorDiNa 8(3), 244-257. https://doi.org/10.5617/nordina.531

Palmberg, I., Jeronen, E., Svens, M., Yli-Panula, E. Andersson, J., \& Johnsson, G. (2011). Blivande lärares (åk 1-6) baskunskaper i Danmark, Finland och Sverige. Kunskaper och uppfattningar om människans biologi. NorDiNa, 7(1), 54-70.

https://doi.org/10.5617/nordina.249

Papageorgiou, G., \& Sakka, D. (2000). Primary school teachers' views on fundamental chemical concepts. Chemistry Education: Research and Practice in Europe, 1(2), 237-247. https://doi.org/10.1039/A9RP90025J

Pedaste, M., Mäeots, M, Siiman, L.A., de Jong, T., van Riesen, S.A.N., Kamp, E.T., Manoli, C.C., Zacharia, Z.C., \& Tsourlidaki, E. (2015). Phases of inquiry-based learning: Definitions and the inquiry cycle. Educational Research Review 14, 47-61.

https://doi.org/10.1016/j.edurev.2015.02.003

Peers, C. E., Diezmann, C. M., \& Watters, J. J. (2003). Supports and concerns for teacher professional growth during the implementation of a science curriculum innovation. Research in Science Education, 33(1), 89-110. https://doi.org/10.1023/A:1023685113218

Pine, K., Messer, D., \& St. John, K. (2001). Children's misconceptions in primary science: Asurvey of teachers' views. Research in Science and Technological Education, 19(1), 79-96. 
Royal Society (2004). Taking a leading role. London, UK: The Royal Society.

Rönnebeck, S., Bernholt, S., \& Ropohl, M. (2016). Searching for a common ground - A literature review of empirical research on scientific inquiry activities. Studies in Science Education, 52(2), 161-197. https://doi.org/10.1080/03057267.2016.1206351

Schoon, K. J., \& Boone, W. J. (1998). Self-efficacy and alternative conceptions of science of preservice elementary teachers. Science Education, 82(5), 553-568. https://doi.org/10.1002/(SICI)1098-237X(199809)82:5<553::AID-SCE2>3.0.CO;2-8

Shulman, L. S. (1986). Those who understand: Knowledge growth in teaching. Educational Researcher, 15(2), 4-14. https://doi.org/10.3102/0013189X015002004

Skamp, K. (2011). Teaching chemistry in primary science: What does the research suggest? Teaching science: The Journal of the Australian Science Teacher Association, 57(4), 37-43.

Smith, R. G. (1997). 'Before teaching this, I'd do a lot of reading': Preparing primary student teachers to teach science. Research in Science Education, 6, 113-127. https://doi.org/10.1007/BF02463038

Smith, K.V., Loughran, J., Berry, A., \& Dimitrakopoulos, C. (2012). Developing scientific literacy in a primary school. International Journal of Science Education, 34(1), 127-152. https://doi.org/10.1080/09500693.2011.565088

Tobin, K. (2006). Analyses of current trends and practices in science education. In: K. Tobin (ed.), Teaching and learning science: A handbook (Vol. 1) (pp. 3-16). London, UK: Praeger.

Van Aalderen-Smeets, S. I., \& Walma van der Molen, J. H. (2015). Improving primary teachers' attitudes toward science by attitude-focussed professional development. Journal of Research in Science Teaching, 52(5), 710-734. https://doi.org/10.1002/tea.21218

Van der Valk, T., \& De Jong, O. (2009) Scaffolding science teachers in open-inquiry teaching. International Journal of Science Education, 31(6), 829-850. https://doi.org/10.1080/09500690802287155

Åhman, N., Gunnarsson, G., \& Edfors, I. (2015). In-service science teacher professional development. NorDiNa, 11(2), 207-219. https://doi.org/10.5617/nordina.2048 